\title{
Managing records at higher education institutions: a case study of the University of KwaZulu-Natal, Pietermaritzburg Campus
}

\author{
A. Chinyemba \\ National Archives of Zimbabwe \\ Harare, Zimbabwe \\ chinyemba@zol.co.zw

\section{P. Ngulube} \\ Information Studies Programme \\ University of KwaZulu-Natal \\ Pietermaritzburg, South Africa \\ ngulubep@ukzn.ac.za
}

\section{Contents}

1. Background and context

1.1 Research questions and rationales

1.2 Scope and limitations

2. Determining the essential records series of the University of KwaZulu-Natal

3. Methodology

4. Records documenting the key functions of the University of KwaZulu-Natal

5. Policies and procedures for managing records at the University of KwaZulu-Natal

6. Level of skills in records management at the University of KwaZulu-Natal

7. Current practice of managing records throughout their life cycle

7.1 Records creation

7.2 Control of records

7.3 Records storage

7.4 Records retention and disposition

7.5 Management of electronic records

7.6 Managing access

8. Role of the University Archives in records management

9. Conclusions and recommendations

10. References

Key words: Records management, university records, University of KwaZulu-Natal. 


\section{Background and context}

Penn, Pennix and Coulson (1994:2) and King (1997:656) pointed out that many business transactions depend on the proper creation and maintenance of recorded information. The medium on which the recording of information could be done may be paper, microfilm, audiotapes, videotapes, photographs, slides, or any computer-readable medium, such as computer tapes or disks, compact disks and optical disks. Gold (1995:1) characterized an organization's management of its records as the 'corporate ... secret weapon' and 'the winning strategy' that give the organization the competitive edge. Yet few organizations, including universities, pay attention to the management of this corporate resource. Despite the fact that universities are continually being called upon to function in a businesses-like manner in order to be self-sustaining and to remain competitive, they overlook the enormous advantages that proper records management practices could contribute to the achievement of their objectives (Mnjama 2002:34; Procter 2002:49).

Recently, the Council on Higher Education (2000:20) pointed out that higher education information systems in South Africa were inadequate. Proper records management could help universities to manage their information, efficiently fulfil their mandate, protect them from litigation, preserve their corporate memory, and foster accountability and good governance. The information contained in university records needs to be managed according to a methodical approach in order to enhance the effectiveness and efficiency of the universities in carrying out their mission.

As universities carry out their mission they create various records. The core business of universities is learning, teaching, research and community development. The University of KwaZulu-Natal, in articulating its mission, states that it is 'committed to academic excellence, innovation in research and critical engagement with society' (University of KwaZulu-Natal 2005). Carrying out these activities produce records, which provide evidence that the University is carrying out its statutory functions. If such records are not properly managed or misplaced, then valuable evidence would be lost forever. Proper management means establishing systematic controls at every stage of the record's life cycle, in accordance with established principles and accepted models of records management.

The University of Melbourne (2001) defines records management as the capturing and maintaining of accurate, complete, reliable and useable documentation of activities of an organization in order to meet legal, evidential, accountability and social/cultural requirements. Records pass through several phases in their life cycle. The primary purpose of a records management programme is to monitor records, regardless of type or format, to ensure that they pass efficiently, and at a minimum cost, through the creation, use, inactive storage and disposal or permanent retention phases (Djorka and Conneen 1984:22).

In addition to facilitating the achievement of the University's mandate, the management of records at the University of KwaZulu-Natal is key to fulfilling the requirements of the Promotion of Access to Information Act No. 2 of 2000 (PAIA) (South Africa 2000) and facilitating the smooth running and integration of the merged universities of Natal and Durban-Westville. The merger is likely to bring about a lot of changes in relation to how the new institution would be run. As Ngulube (2004a:23) points out:

'Change brings uncertainty, but records make decision making during uncertainty possible. Changes that are not informed by reliable information are likely to be unsustainable, unjustifiable and lacking transparency.' 
In this regard, properly managed records may foster accountability, transparency and good governance in the University of KwaZulu-Natal, which resulted from the merged institutions.

Furthermore, the passing of PAIA by the South African government makes the management of university records of great importance. The Act gives the public the right of access, upon request, to records held by public or private bodies, to the extent that a requested record is required for the exercise or protection of rights (Currie and Klaaren 2002:1). Compliance with the requirements of the Act means that the University must have in place a comprehensive records management programme that maps all the records of the University (Currie and Klaaren 2002).

In this light, the proper management of university records at a South African institution becomes very important. Universities might find themselves in an embarrassing position if requested records are not found as a result of poor records systems where, as Taylor (2000:240) notes, litigation by aggrieved parties cannot be ruled out. Recently, a former University of Durban-Westville student made a court application demanding to see his examination scripts (UKZN rejects marks allegations 2004). Although, the student eventually lost his case at the Pietermaritzburg High Court, the case demonstrates the possibly consequence of not providing information timeously.

Organizations that manage their records well reap immediate benefits in terms of being able to utilize all available information resources for competitive advantage. Kemoni and Wamukoya (2000:125) state that effective records management systems provide information required for the proper functioning of organizations, including universities. On the other hand, poor records management can be risky to organizations. Djorka and Conneen (1984:22) summarize the consequences of poor records management as follows:

'[I]n an institution where paperwork is poorly managed, the flow of records through the life cycle is retarded, chaotic, or non-existent. Records and the information they contain are difficult to retrieve, and costly duplication of paperwork is a frequent occurrence. The net effect of poor management is a decrease in the efficiency of the institution and an inflation of its operating costs.'

\subsection{Research questions and rationales}

The University of KwaZulu-Natal has a distributed system of managing records with no central authority responsible for the records management function. A distributed management strategy ensures that records are accessible over time by letting them be maintained in the agencies that create or manage them (National Archives of Australia 1998). The records that are created by the University's constituent department are kept and managed by the creating units. This means that both faculty and school offices manage the records they create or receive in the conduct of the business of the University. Within a school or faculty, the records are centrally managed under the school or faculty manager or administrator who has overall responsibility for the records of his or her unit. While there are no standard structures, at times records management responsibilities are delegated to administrative officers who often have responsibility for a sector of the records, such as student records or finance and administration records.

Despite the important role that records play, there is overwhelming evidence that the management of university records has largely been neglected (Choongo 1998; Kemoni and Wamukoya 2000; Mnjama 2002; Oyiti 1998; Procter 2002; Taylor 2000; Uwaifo 2004; 
Wema 2003). How universities manage their records should be a problem of concern to researchers. It was therefore important to investigate the current state of records management at the University of KwaZulu-Natal, Pietermaritzburg in order to find out if the University was managing its records in accordance with the established principles of records management. The investigation was guided by the following questions:

- Which records document the key functions and activities of the University?

- What mechanisms, policies, rules and procedures are in place for managing records in the University?

- What is the level of skills in records management in the University?

- What is the current practice of managing records throughout their life cycle?

- What role, if any, does the University Archives currently play in the management of University records?

- Based on the findings of the study, what recommendations can be made to improve records management at the University?

By asking questions about current practices and procedures in records management, the study managed to raise an awareness of a need for their proper management. The study is likely to form the basis of corrective action and policy formulation if the recommendations that have been made are taken into account.

\subsection{Scope and limitations}

The study was limited to faculties and schools located on the Pietermaritzburg campus of the University of KwaZulu-Natal. All the offices that participated in the study were located on the same campus though the University has four other campuses, namely, Edgewood College, Howard College, Medical School and Westville. The survey of all campuses was deemed unnecessary because the overall picture of how records are managed at the University of KwaZulu-Natal is an aggregate picture of the records management practices and procedures on all campuses of the University. Admittedly, different units are likely to be motivated differently on how to manage their records, but guiding principles are likely to be similar university-wide. Therefore, this research studied practices and procedures of records management in the offices where schools and faculties manage their records on the Pietermaritzburg campus.

\section{Determining the essential records series of the University of KwaZulu-Natal}

Functional analysis provides a systematic way of establishing the key activities and transactions pertaining to the key functions of an organization, and in determining the records that support those activities and transactions. Therefore, as Robinson (1999) notes, functional descriptions link records directly to the business functions and activities that created them.

Samuels (1992:22) used the functional approach in her study. The functional framework developed by Samuels (1992) and lists maintained by other university records management systems, such as at the University of Cincinnati (2002) and the University of Melbourne (2001), were used in this study to determine the essential records that the University of KwaZulu-Natal should maintain. A summary of the records generated by the functional analysis of university activities is presented below. It is evident from the list that the key functions of universities are conveying knowledge, conferring credentials, fostering 
socialization, conducting research, sustaining the institution and providing public service (Samuels1992:20).

This is the list of essential records that provide evidence of University functions:

\section{A. Confer credentials}

- Admission policy

- Applications received

- Selected students

- Registered students

- Personal files of students

- Enrolment reports

- Financial aid policy

- Scholarships and awards available

- Students awarded degrees

- Masters or doctoral theses passed

- Photographs of graduation ceremonies

- Videos of graduation ceremonies

\section{B. Convey knowledge}

- Courses run by the unit

- Curriculum of the courses run

- Course modules

- Complete list of current teaching staff

- Teaching responsibilities allocations

- Timetables and class venues

- Class lists

- Attendance lists

- Student continuous assessment marks

- Samples of assignments given

- Examination questions

- Student examination scripts

- Student evaluation policy

- Staff evaluation policy

- Student evaluations of lecturers

- Peer evaluation by other lecturers

\section{Conduct research}

- Research proposal submitted

- Proposals accepted

- Research grants management

- Annual reports of research output

\section{Sustain the institution}

- Evidence of establishment of unit

- Mission statement of unit

- Governing board minutes and reports

- Unit committees minutes and reports

- Organizational chart of unit

- Budget proposals and submissions 
- Expenditure records

- Audit reports

- Personnel policy

- Current employment regulations

- Staff recruitment in the unit

- Performance appraisals

- Outside earnings

- Staff development and training

- Unsolicited applications

- Plan of facilities of the unit

- Current space use and planning

- Security arrangements for facilities

- Architectural drawings of buildings

- Maintenance of facilities

\section{E. Provide public service}

- Continuing education programmes

- Consultation and other services

- Research services available

- Technical assistance available

- Projects undertaken

- Winter school records

\section{Methodology: the research story}

The research question guided the design of the research in terms of what data were needed to answer the question, where the data were, how data were to be collected and how they were to be analysed (Durrheim 1999:29; Rowley 2002:18). Using the survey approach, the researchers were able to collect data on the different practices of records management in different faculties and schools located in different parts of the University of KwaZulu-Natal, Pietermaritzburg campus. Similar studies carried out elsewhere by researchers, such as Nwosu (1993) and Ugwunze (1992), used the same methodology.

Faculties and schools that constituted the University were selected as the administrative units from which information was collected on the basis that these units carried out the core activities of the University. The respondents comprised faculty managers who were in charge of the management of the entire faculty records, faculty officers who were responsible for the management of sectors of the records, such as undergraduate or postgraduate records, school managers or administrators who had overall responsibility for managing the school records and administrative officers who had sectional responsibility for records in the school.

The population was identified from the detailed University of KwaZulu-Natal telephone directory that listed employees and their designations, according to their departments. A total of 42 respondents were identified. Thirteen of the participants were from faculty offices while 29 were from school offices. The total population was studied.

The researchers settled on a combination of data collection tools with the questionnaire as the principal instrument of data collection. Observations and interviews were employed to supplement the questionnaire. In research, the use of various methods to collect the same data or triangulation is highly commendable. Previous studies by Choongo (1998), Kemoni and Wamukoya (2000), Nwosu (1993), Ugwunze (1992) and Uwaifo (2004) used a 
combination of these research tools in varying ways.

The questionnaire content was informed partly by the stages of the records life cycle model as outlined by Robek, Brown and Stephens (1995:7-8), the stages of the records continuum model as identified by the Edith Cowan University (2001) and by the model action plan (MAP) (Edward and McLeod 2004). The questionnaire itself consisted of 99 items considered necessary for the collection of the data needed to answer the research question.

The pre-tested questionnaires were delivered in person by the researchers in order to establish rapport with the respondents and encourage questionnaire return. The returned questionnaires were edited, coded and captured into an SPSS matrix. The data were analysed using the various themes of the research questions that guided the investigation.

Of the 42 questionnaires distributed, 38 were returned, representing a 90\% return rate. However, two of the 38 questionnaires were returned uncompleted. The respondents claimed that they did not find the time to complete them. Thirty-six $(85,7 \%)$ of the questionnaires were completed correctly and were, therefore, useable. Thirteen $(36,1 \%)$ questionnaires originated from faculty offices while $23(63,9 \%)$ originated from school offices. The response rate was considered to be adequate in accordance with the statement of Babbie and Mouton (1998:261) that the consensus in survey research is that a response rate of $50 \%$ is considered adequate for analysis, while $60 \%$ is good and $70 \%$ is considered very good.

\section{Records documenting the key functions of the University of KwaZulu-Natal}

The primary purpose of records management is to ensure that all the records that provide the evidence that the organization is carrying out its mandate are captured. Records are the basis for organizational accountability, complying with legislative requirements and the development of a corporate memory for the University. For records to be able to do that they must be complete, accurate and reliable evidence of the transactions conducted (University of Melbourne 2001).

The results revealed that the most common records series maintained by offices were those that provide evidence to ascertain that the University was carrying out its core activity of conveying knowledge. The full list of the frequencies of the records series maintained in the schools and faculties that were investigated is presented in Table 1.

Table 1 Frequencies of essential records series maintained in the offices

\begin{tabular}{|l|l|r||l|l|l|r|}
\hline \multicolumn{2}{|l|}{ Record Series } & $\%$ & \multicolumn{2}{|l|}{ Record Series } & $\%$ \\
\hline 1 & Course modules & 80,7 & 30 & Current employment regulations & 25,0 \\
\hline 2 & Registered students & 75,0 & 31 & Maintenance of facilities & 22,2 \\
\hline 3 & Personal files of students & 75,0 & 32 & Staff development and training & 22,2 \\
\hline 4 & Courses run by the unit & 66,7 & 33 & Staff recruitment in the unit & 22,2 \\
\hline 5 & Curriculum of the courses run & 66,7 & 34 & Organizational chart of unit & 22,2 \\
\hline 6 & Class lists & 61,1 & 35 & Annual reports of research & 22,2 \\
& & & & output & \\
\hline 7 & Applications received & 58,3 & 36 & Student evaluation policy & 19,4 \\
\hline 8 & Students awarded degrees & 55,6 & 37 & Samples of assignments given & 19,4 \\
\hline 9 & Selected students & 55,6 & 38 & Plan of facilities of the unit & 19,4 \\
\hline 10 & Complete list of current & 52,8 & 39 & Current space use and planning & 19,4 \\
\hline
\end{tabular}




\begin{tabular}{|c|c|c|c|c|c|}
\hline & g staff & & & & \\
\hline 11 & Timetables and class venues & 50,0 & 40 & Audit reports & 19,4 \\
\hline 12 & Examination questions & 50,0 & 41 & Performance appraisals & 19,4 \\
\hline 13 & Expenditure records & 47,2 & 42 & Financial aid policy & 19,4 \\
\hline 14 & $\begin{array}{l}\text { Unit committees minutes and } \\
\text { reports }\end{array}$ & 44,4 & 43 & Personnel policy & 16,7 \\
\hline 15 & Attendance lists & 41,7 & 44 & Outside earnings & 13,9 \\
\hline 16 & $\begin{array}{l}\text { Student continuous assessment } \\
\text { marks }\end{array}$ & 41,7 & 45 & Consultation and other services & 13,9 \\
\hline 17 & Student examination scripts & 41,7 & 46 & Staff evaluation policy & 13,9 \\
\hline 18 & $\begin{array}{l}\text { Masters or doctoral theses } \\
\text { passed }\end{array}$ & 38,9 & 47 & Student evaluations of lecturers & 11,1 \\
\hline 19 & $\begin{array}{l}\text { Governing board minutes and } \\
\text { reports }\end{array}$ & 36,1 & 48 & Unsolicited applications & 11,1 \\
\hline 20 & Admission policy & 36,1 & 49 & Research grants management & 11,1 \\
\hline 21 & Enrolment reports & 36,1 & 50 & $\begin{array}{l}\text { Evidence of establishment of } \\
\text { unit }\end{array}$ & 11,1 \\
\hline 22 & Mission statement of unit & 33,3 & 51 & Research services available & 8,3 \\
\hline 23 & $\begin{array}{l}\text { Budget proposals and } \\
\text { submissions }\end{array}$ & 30,6 & 52 & Technical assistance available & 8,3 \\
\hline 24 & $\begin{array}{l}\text { Teaching responsibilities } \\
\text { allocations }\end{array}$ & 30,6 & 53 & Projects undertaken & 8,3 \\
\hline 25 & Proposals accepted & 27,8 & 54 & $\begin{array}{l}\text { Continuing education } \\
\text { programmes }\end{array}$ & 5,6 \\
\hline 26 & $\begin{array}{l}\text { Security arrangements for } \\
\text { facilities }\end{array}$ & 27,4 & 55 & $\begin{array}{l}\text { Architectural drawings of } \\
\text { buildings }\end{array}$ & 5,6 \\
\hline 27 & Research proposal submitted & 25.0 & 56 & $\begin{array}{l}\text { Peer evaluation by other } \\
\text { lecturers }\end{array}$ & 2,8 \\
\hline 28 & $\begin{array}{l}\text { Scholarships and awards } \\
\text { available }\end{array}$ & 25,0 & 57 & $\begin{array}{l}\text { Photographs of graduation } \\
\text { ceremonies }\end{array}$ & 2,1 \\
\hline 29 & Winter school records & 25,0 & 58 & $\begin{array}{l}\text { Videos of graduation } \\
\text { ceremonies }\end{array}$ & 2,1 \\
\hline
\end{tabular}

The University of KwaZulu-Natal operates under an environment of both external and internal accountability. It has a specific mandate in terms of the Higher Education Act (Act No. 101 of 1997) as amended (South Africa 2002) under which it was established and, therefore, it is also accountable to outside bodies. It is essential that records showing that the University is carrying out its mandate be maintained. Furthermore, the University is internally accountable to itself in terms of its strategic plans. Records are the only means of showing that the University is accountable.

It is essential that the University, particularly in its faculties and schools, identifies and maintains records series that provide evidence of its core activities of teaching, learning research and the provision of public services. Indeed these are the key areas for faculties, and sometimes records about these activities may not exist anywhere else on campus. In the area of management it is possible that records not captured or maintained by the schools or faculties may be maintained by central administration.

As shown in Table 1, the University was capturing and maintaining various essential records series particularly in the key areas of conveying knowledge and conferring credentials. 
Twenty-seven (75\%) of the offices indicated that they kept lists of registered students and personal files of students while 55,6\% kept lists of past students who had been awarded degrees. By maintaining these records the University could show that it was conducting its core business.

However, what was disturbing was the discrepancy in the percentages of record series that captured activities related to conveying knowledge. It was found that $11(30,6 \%)$ respondents kept record series relating to teaching responsibilities allocations. Only four $(11,1 \%)$ of these offices kept records relating to student evaluations of lecturers and one $(2,8 \%)$ kept records on peer evaluation of lecturers. The fact that 27 (75\%) respondents had files relating to registered students indicated that most offices had something to do with conveying knowledge to students. The low percentage of records that were being kept relating to evaluation of lecturers might mean that some offices were not capturing the records, or the exercise was not conducted at all. Yet, monitoring and evaluation are some of the keys that give organizations a competitive advantage.

In the area of conducting research, which is also a key area, the University was not doing so well. Only $10(27,8 \%)$ offices indicated that they maintained records of research proposals accepted by the unit and 13 (38,9\%) indicated they kept records of masters and doctoral theses passed by the unit. These records are essential in providing evidence of what research has been carried out in the unit before, to avoid unnecessary repetition and cheating by students.

It is likely that records were also poorly captured and maintained in the area of the provision of public services with only two $(5,6 \%)$ offices maintaining a record of continuing education programmes available in the unit and five (13,8\%) maintaining a record of consultation and other services available from the unit. It is possible that very few of the units under study were engaged in providing continuing education, for example, and thus did not need to keep records of that activity. The provision of public services is one important area where the University could realise commercial viability if managed properly.

The fact that only 12 (33,3\%) had mission statements for their record units, and eight $(22,2 \%)$ had records that related to organizational charts of the unit partly explains why some essential records were not being kept. A mission statement firstly indicates what the organization seeks to accomplish, that is why the organization exists and the ultimate result of its work (Meshanko 1996). Secondly, it outlines the activities or programmes the organization chooses in order to pursue its purpose. It also provides values that guide the members of the organization in performing their work. Without a mission statement, it is extremely hard to effectively execute an organization's core programmes. The words of Lewis Caroll through the Cheshire Cat in Alice in Wonderland eloquently summarized the importance of mission statements: 'If you don't know where you are going, it doesn't matter which way you go' (Cheshire Cat 2001). It is evident that the University records officers must articulate a clear sense of their mission and purpose so that their activities are guided by a clear vision. That would enable them to capture the records series that provide evidence of the University's core business.

The researchers concede that a generic list was used and because of the peculiarities of each office and the different specialisations of the offices, the lists may not have applied equally to each unit. However, the results remain an indication that there existed a problem in the area, which may warrant further investigation. 
Records management programmes operate within the framework of policies, rules and procedures that give guidance to practice. The purpose of these is to provide an environment conducive to proper records management. This is particularly important in an environment, such as the University of KwaZulu-Natal, where the responsibility for records management is distributed among the individual units with little or no centralized control. Policy is essential to provide broad guidelines in which procedures may be developed.

Four $(11,1 \%)$ respondents indicated that there was a general records management policy. The highest number, 12 (33,3\%), indicated that there was a written document specifying responsibility for records management. This was understood by the researchers to be incorporated in the job descriptions of the staff concerned. The results show that policies for managing records were inadequate. The details of the areas covered by their records management policies are presented in Figure 1.

Figure 1 Aspect covered by records management policies

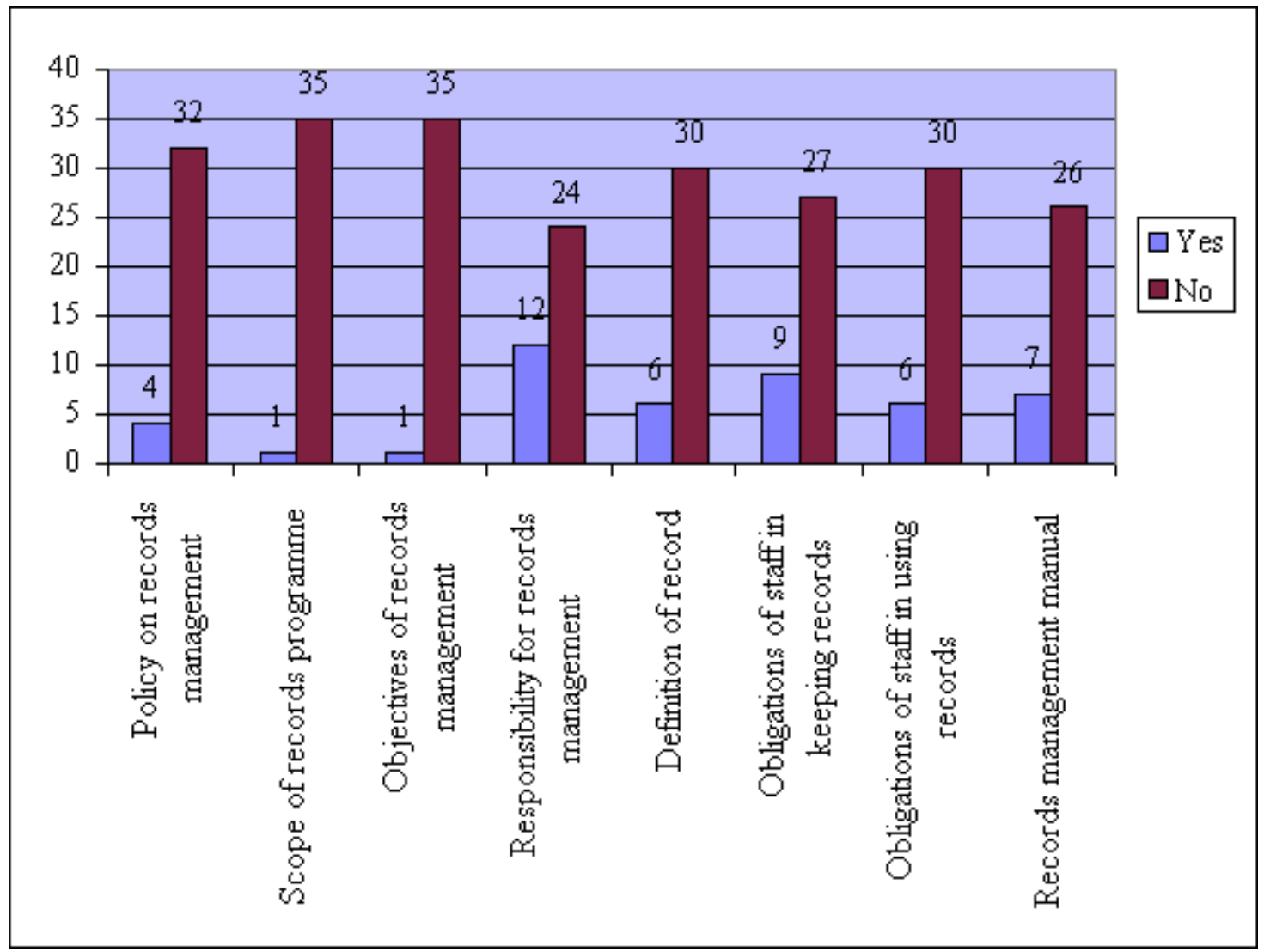

In the absence of an established policy environment and without written procedures to guide development, the respondents were asked how practices and procedures for records management were developed in their offices. The majority, 20 (55,6\%), cited individual initiative, with only four $(11,1 \%)$ citing advice from the University archivist. Taylor (2000:241) and Mnjama (2002:31) suggest that the evidence of the neglect of records management in universities is the lack of co-ordinated and planned programmes within these institutions as well as an absence of policies, procedures and facilities for managing records.

In addition to policies, there is a need to have standards in place that identify best practices and benchmarks in order to achieve uniformity in practice. There is also a need for mechanisms to check compliance with policies, rules and procedures. One such mechanism would be the conducting of record management system audits. Ricks, Swafford and Gow (1992:457) describe a records management system audit as 'a regularly scheduled 
examination and verification of a specific activity' to enforce compliance with established policies by making individuals and departments accountable.

Nine (25\%) of the respondents indicated that an audit had been carried out in their offices. A general records management audit was conducted in only three $(8,3 \%)$ of the offices, while an audit specifically checking if all records were being captured into the system was reported in only six $(16,7 \%)$ offices. An audit for security of records was conducted in only three $(8,3 \%)$ while an audit for unauthorized destruction of records was conducted only in one (2,8\%) office. The frequency of the audits ranged from two to 24 months. When the lack of audits is viewed against the fact that retention schedules were reported in only six $(16,7 \%)$ offices, it could mean that the University was most probably losing valuable evidence of its activities.

The results of the survey showed that only seven $(19,4 \%)$ of the offices indicated that they had a records management manual. Robek et al. (1995:435) state that:

'[The manual] establishes the various phases of the records management programme, assists with training of employees, saves money, reduces errors, standardises procedures, increases productivity and makes provision for change.'

In this regard, a records management manual serves as a reference point for records management staff and ensures the standardization of procedures. The existence of a manual is critical in an organization such as this one where there seemed to be no central repository of expertise for records management practices.

\section{Level of skills in records management at the University of KwaZulu-Natal}

The existence of qualified staff in records management ensures that the work is carried out efficiently. Ugwunze (1992:44) and Uwaifo (2004:89) stress that records management had little prospect of success unless the services of trained personnel were employed. Education and training are important because they impart new skills and give confidence to personnel (Wamukoya 2000:31; Ugwunze 1992:43).

Only three $(8,3 \%)$ indicated that they had qualifications in records management. When asked to name the qualifications only one of the respondents indicated a National Diploma in Secretarial Studies. Ten $(27,8 \%)$ of the respondents indicated they had attended training in some aspect of records management since they started working with records.

It is evident from the results that the University lacks personnel with formal qualification in records management and does not seem to provide consistent continual training for its staff. However, the University boasts of cumulative experience in records management. Twentyfive $(69,4 \%)$ of the records management staff had been working with records for more than three years, while a combined total of $30(83,2 \%)$ have been with records for more than two years.

\section{Current practice of managing records throughout their life cycle}

The management of the records after their creation is just as important as ensuring that the right records have been captured. If the basic premise of records management, which is to 'manage organisational information so that it is timely, accurate, complete, cost-effective, 
accessible and usable' (Robek et al. 1995:7), is to be realized, then proper controls must be applied to records during the different stages they pass through from creation to disposal. This ensures that records maintain their value as authentic evidence of activity throughout their life cycle.

\subsection{Records creation}

The prime objective of records creation is to ensure that only records needed by the system are created and enter the system (Penn et al. 1994; Shepherd and Yeo 2003). The results of the survey indicate that 19 (52,8\%) respondents had in place a list of activities for which records were to be created and only $12(33,33 \%)$ respondents had instructions specifying the number of copies to be made. The implication of the results is that not only might unnecessary records have been created, but that some important activities may also have been overlooked in the creation of records.

The generation of records needs to be managed because this is where the records enter the records system. Penn et al. (1994:14) state that 75\% of the cost of information is in records creation. Universities are information intensive organizations and as such generate a large amount of records. Unless controls are instituted at the point where the records enter the system, unnecessary costs would be incurred and there is danger that the system would be inundated and fail to function properly.

\subsection{Control of records}

The proper management of records entails establishing physical and intellectual control over records that are entering the records system. This is done through registering each record as it enters the system, locating it where it can be found easily by means of classification schemes, placing it into files that are properly titled and indexing the information in the records. When records are used by several people, and when records can be taken out of the office for use elsewhere, it means keeping track of where the record is and for how long, if the record is not to be lost.

The results of the survey showed that only 15 (41,7\%) of the offices registered the records as they entered the system, while 21 (58,35\%) of the offices indicated they had responsibility for classifying records. This was despite written classification systems being available in only 10 (27\%) of the offices. The implication is that more than half of the offices managing records at the University were not registering the records that came into the University records system. The absence of a written classification scheme meant that records were not classified consistently. Inconsistent titling could also become a problem if 25 (69,4\%) offices reported that they had responsibility for opening new files yet only five $(13,9 \%)$ indicated that they had a list of authorized terms that could be used in the titles of new files.

The tracking of records was also problematic as only two (5,6\%) respondents kept track of their files. Yet, 25 (69,4\%) of the respondents had files that were used by more than one person. Even when the right records were created they would not be of much use unless they could be found and utilized in the system when required. It seemed that the standard practice was that users found the records because 'the users know the system', as one respondent claimed.

\subsection{Records storage}

Records storage is largely concerned with the storage of records that are no longer constantly referred to but are occasionally needed for business. These are semi-active and inactive records. These records often safeguard 'crucial organisational interests hence the need to 
keep them for as long as they may be needed' (Penn et al. 1994:208). Keeping these records implies identifying them so that they can be separated from active records and then storing them away from expensive office space.

The result of the survey indicated that four $(11,1 \%)$ of the offices had guidelines for the identification of active, semi-active and inactive records. Only six $(16,7 \%)$ offices had criteria for identifying active records and seven $(19,4 \%)$ had procedures in place for transferring identified records to records storage. Seventeen $(47,2 \%)$ kept semi-active and active records together. Only three $(8,3 \%)$ respondents transferred records to the University Archives.

Wema (2003) suggests that keeping active and inactive records together poses serious storage and retrieval problems. The findings of this research showed that expensive office space was wasted on storing records which could be moved to less expensive space, such as archives. This also had an important bearing on the ultimate disposition of these records when their retention time had expired. If they could not easily be identified, then they could not easily be disposed of.

\subsection{Records retention and disposition}

A records retention and disposal programme is crucial to the management of the records of the organization. The benefits of a retention and disposition programme are aptly summarized by Ricks et al. (1992:75-76) as follows:

'A records retention programme provides a timetable and consistent procedures for maintaining the organisation's records, moving the records to inactive storage when appropriate and destroying records when they are no longer valuable to the organisation.'

The results of the survey indicated that inventory lists existed in only two (5,6\%) offices. Six $(16,7 \%)$ offices had retention and disposition schedules. Yet 27 (75\%) respondents reported regular disposal of records from their offices. Even though $22(61,1 \%)$ offices indicated that they had disposed records within the past twelve months, only five $(13,9 \%)$ respondents indicated that they maintained a list of records disposed from their offices. This means that almost every office on campus was disposing of records yet no one had any idea of what they threw away. This could have serious implications if such records were to be required in litigation and could not be located without any evidence of their disposal according to disposal schedules.

The absence of record retention schedules suggested that some of the records that were no longer needed by the system were still kept, and those that were still needed by the system might have been destroyed. Another implication is that the University might have been losing valuable evidence and vital memory as records disposition had not been developed systematically. The need to develop records disposition schedules by universities is emphasized by Nwosu (1993).

It is, however, of interest to note that the researchers were able to locate a records disposition list at the University Archives. The researchers could not establish how and when the list was drawn up, or if it was ever implemented. However, the list did not seem to adequately cover the essential records series discussed in the previous sections.

\subsection{Management of electronic records}


The rationale for including the management of electronic records, as a separate section from the management of other records, was to highlight the fact that electronic records pose new challenges as compared to paper-based records. Although paper records remain predominant in organizations, there is no doubt that record keeping is increasingly becoming digital (Edith Cowan University 2002). The presence of personal computers in every office and a local area network at the University of KwaZulu-Natal shows that the University is increasingly making use of digital records; they are continually being generated in electronic format and may exist only in that format.

The results showed that the management of electronic records was unsatisfactory. The full results of the survey are presented in Table 2. However, managing electronic records has remained a nightmare to many institutions in Africa (Ngulube 2004b). It is evident from Table 2 that the management of e-records was fragmented and vital records were in danger of being lost.

Table 2 Management of electronic records at the University of KwaZulu-Natal

\begin{tabular}{|l|r|r|c|c|c|c|}
\hline \multirow{2}{*}{ Control activity } & \multicolumn{2}{|c|}{ Yes } & \multicolumn{2}{c|}{ No } & \multicolumn{2}{c|}{ Total } \\
\cline { 2 - 7 } & No. & \% & No. & \% & No. & \% \\
\hline Identification of electronic records & 13 & 36,1 & 23 & 63,9 & 36 & 100 \\
\hline Control on generation of unnecessary records & 8 & 22,2 & 28 & 77,8 & 36 & 100 \\
\hline List of activities for records creation & 8 & 22,2 & 28 & 77,8 & 36 & 100 \\
\hline Guidelines for registering electronic records & 13 & 36,1 & 23 & 63,9 & 36 & 100 \\
\hline Guideline for organisation of records & 7 & 19,4 & 29 & 80,6 & 36 & 100 \\
\hline Separate storage of semi-active records & 7 & 19,4 & 29 & 80,6 & 36 & 100 \\
\hline Storing records on removable media & 18 & 50,0 & 18 & 50,0 & 36 & 100 \\
\hline Guidelines for labelling removable media & 9 & 25,0 & 27 & 75,0 & 36 & 100 \\
\hline Protection and security of electronic records & 4 & 11,1 & 32 & 88,9 & 36 & 100 \\
\hline Retention schedules & 1 & 2,8 & 35 & 97,2 & 36 & 100 \\
\hline Checking compliance & 1 & 2,8 & 35 & 97,2 & 36 & 100 \\
\hline Guidelines on methods of disposal & 3 & 8,3 & 33 & 91,7 & 36 & 100 \\
\hline Guidelines to save e-mail records & 11 & 30,6 & 25 & 69,4 & 36 & 100 \\
\hline Preservation of electronic records & 1 & 2,8 & 35 & 97,2 & 36 & 100 \\
\hline
\end{tabular}

\subsection{Managing access}

The records of an organization can only be useful to the organization if they are accessible to the members of the organization who need to use them. This implies making sure that they are readily retrievable when required. When asked to indicate the tools of retrieval in place to facilitate access to records, 28 (77,8\%) respondents indicated that their drawers were labelled, seven $(19,9 \%)$ had indices and eight $(22,2 \%)$ had automated retrieval systems.

Access is also concerned with making arrangements to comply with access requirements whether from within the institution or from without. This is particularly important in the light of the recent passing of PAIA. The results showed that although nine (25\%) of the respondents indicated that they had guidelines for the identification of requirements to make records accessible to those who needed them, none of the respondents had a copy of PAIA in their office. In fact, five records management staff, including a school manager, had never heard of the Act. 
It is evident that while provision for internal access to records was satisfactory, provisions for external access were poor. These results meant that the University was especially ill prepared to deal with external access requirements.

\section{Role of the University Archives in records management}

Archivists have an interest in the management of records throughout their life cycle because the quality of archival records depends on how they have been handled through their life cycle. Maher (1992:283) states that records management is fundamental to the archival function and, therefore, the archivist should pursue an active role in the management of the institution's records. The archivist's involvement in records management is essential throughout the stages of the life cycle.

An interview with the University archivist established that the University Archives played a less than peripheral role in the management of the University's current records. Results of the survey showed that only two (5,6\%) respondents had sought assistance from the University archivist. The University Archives had a role to play in the management of the current records of the University. The archivist indicated the Archive's willingness to be involved in the formulation of records management policies or guidelines.

\section{Conclusions and recommendations}

The results of the survey showed that the University fell below requirements when it came to maintaining records series that document its functions. The study also demonstrated that the mechanisms in place for the management of records were inadequate to provide an environment in which records management objectives could be achieved. The desirable controls at each stage of the records life cycle were also found to be inadequate. The findings showed that, in the absence of guidelines records management, practices and procedures were developed through individual initiative. The study indicated that the University Archives was playing a limited role in the management of current records in the creating units. Knowledge of legal requirements relating to access to information was limited.

In light of the above, it is recommended that the University carries out a functional analysis of its key functions, activities and transactions in order to establish guidelines to identify the essential records series that need to be captured and maintained in its records system. Policies that provide a framework within which the University records may be managed should be established. Once policies are established it would also be necessary to ensure that there is a consistent way of checking compliance and evaluating the performance of the system through records management system audits. An inventory of all record series of the University should be made and a retention schedule developed and implemented without delay.

Records management manuals should also be developed to provide a reference point for practices and procedures while helping to standardize records management activities in the University. The University should facilitate continual training in records management, particularly in the face of current changes in the information field. It is particularly important that all those in charge of records, especially in faculties and schools, be made aware of access requirements and that mechanisms for compliance with that access be provided. 
environment. It is also recommended that the University Archives assume its rightful role in the management of records throughout their life cycle. The University Archives is the repository of expertise of records management procedures and the fact should be publicized to departments.

However, there is need to replicate this research in other universities in South Africa in order to build up evidence to refute or confirm that university records are not well managed. The study was confined to the schools and faculties of the University. There is also need to extend the research to other offices that handle University records in order to establish the practices and procedures there. Furthermore, this study focused on records management from the point of view of records managers; there is also a need to evaluate the service from a user's point of view. Finally, there is a need to carry out research to establish effective ways of preserving electronic records of archival value in the universities.

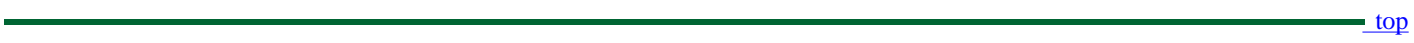

\section{References}

Babbie, E. and Mouton, J. 2001. The practice of social research. South African edition. Cape Town: Oxford University Press.

Cheshire Cat. 2001. The Cheshire Cat. [Online] Available WWW:

http://www.ruthannzaroff.com/wonderland (Accessed 12 February 2003).

Choongo, M.W. 1998. Justification for setting up an archives at the University of Zambia: problems and prospects. African Journal of Library, Archives and Information Science 8 (2):77-88.

Council on Higher Education. Size and Shape Task Team . 2000. Towards a new higher education landscape: meeting the equity, quality and social development imperatives of South Africa in the 21 st Century. [Online] Available WWW:

http://www.che.org.za/documents (Accessed 30 March 2004).

Currie, I. and Klaaren, J. 2002. The Promotion of Access to Information Act commentary. Clarendon (S.A.): Siber INK.

Djorka, J. and Conneen, S. 1984. Records management as an appraisal tool in college and university archives. In: Peace, N.E. (ed.) Archival choices. Ottawa: D.C Heath and Company: 19-60.

Durrheim, K. 1999. Research design. In: Terre Blanche, M. and Durrheim, K. (eds). 1999. Research in practice: applied methods for the social sciences. Cape Town: UCT Press: 2955.

Edith Cowan University. 2001. The records continuum. [Online] Available WWW: http://www.scis.ecu.edu.au/ (Accessed 25 March 2002).

Edith Cowan University. 2002. The challenge of electronic recordkeeping. [Online] Available WWW: http://www.scis.ecu/edu.au/ (Accessed 8 July 2002).

Edward, S. and McLeod, J. 2004. Is the Freedom of Information Act driving records management in further education colleges? Records Management Journal 14(1):40-50.

Gold, G. 1995. How to set up and implement a records management system. New York: 
American Management Association.

Kemoni, H. and Wamukoya, J. 2000. Preparing for the management of electronic records at Moi University, Kenya: a case study. African Journal of Library, Archives and Information Science 10(2):125-138.

King, L.A. 1997. Are you managing your vinyl effectively? Management Decisions 35 (9):656-659.

Maher, W. 1992. The management of college and university archives. London: Scarecrow.

Meshanko, R. 1996. What should our mission statement say? [Online] Available WWW: http://www.nonprofits.org/npofaq/03/21.html (Accessed 10 March 2003).

Mnjama, N.M. 2002. Managing university records. ESARBICA Journal: Journal of the Eastern and Southern Africa Regional Branch of the International Council on Archives $21: 32-40$.

National Archives of Australia. 1998. Archives advice 24: distributed management of electronic records. [Online] Available WWW: http://www.naa.gov.au/recordkeeping/ (Accessed 11 November 2002).

Ngulube, P. 2004a. Fostering accountability and justice: opportunities for records managers in changing societies. ESARBICA Journal: Journal of the Eastern and Southern Africa Regional Branch of the International Council on Archives 23:23-32.

Ngulube, P. 2004b. Implications of technological advances for access to the cultural heritage of selected countries in sub-Saharan Africa. Government Information Quarterly: An International Journal of Information Technology Management, Policies, and Practices 21 (2):143-155.

Nwosu, C.O. 1993. Records and information management at the University of Nigeria, Nsukka. The Nigerian Archives 4:27-35.

Oyiti, M. 1998. Records and archives management in academic institutions: a case study of the University of Botswana. MIS thesis. Gaborone: University of Botswana.

Penn, I.A., Pennix, G.B. and Coulson, J. 1994. Records management handbook. 2nd ed. Aldershot (Hants): Gower.

Procter, M. 2002. One size does not fit all; developing records management in higher education. Records Management Journal 12(2):48-54.

Ricks, B., Swafford, A.J. and Gow, K.E. 1992. Information and image management: a records systems approach. 3rd ed. Cincinnati, OH: South-Western.

Robek, M.F., Brown, G.F. and Stephens, D.O. 1995. Information and records management: document based information systems . New York: Glencoe/McGraw-Hill.

Robinson, C. 1999. Functional analysis and keyword classification. Paper presented at the ARMA 1999 Seminar: Managing Change - A Blueprint for the Future. Edmonton, Alberta, Canada.

Rowley, J. 2002. Using case studies in research. Managing Research News 25(1):16-27. 
Samuels, H.W. 1992. Varsity letters: documenting modern colleges and universities. Metuchen, N.J: The Society of American Archivists.

Shepherd, E. and Yeo, G. 2003. Managing records: a handbook of principles and practice . London: Facet.

South Africa . 2000. Promotion of Access to Information Act No. 2 of 2000. Republic of South Africa Government Gazette Vol. 416 No. 20852.

South Africa . 2002. Higher Education Act No. 101 of 1997 as amended . [Online] Available WWW: http://education.pwv.gov.za/ (Accessed 25 June 2002).

Taylor, M. 2000. Records management at tertiary institutions in the SCECSAL region at the dawn of the new millennium. In: Chisenga, J., Chitambo, A. and Onyango, F. (eds).

Information 2000: a vision for the SCECSAL region . Windhoek: Namibian Information Workers Association: 239-245.

Ugwunze, I.V. 1992. An examination of records management in the University of Lagos registry. African Journal of Library, Archives and Information Science 2(1):39-46.

UKZN rejects marks allegations. 2004. The Natal Witness (8 October). [Online] Available WWW: http://www.witness.co.za/default.asp. (Accessed 8 October 2004).

University of Cincinnati . 2002. University records management program: suggested record series. [Online] Available WWW: http://www.archives.uc.edu/ (Accessed 30 October 2002).

University of KwaZulu-Natal . 2005. Premier university of African scholarship. [Online] Available WWW: http://www.ukzn.ac.za/ (Accessed 2 January 2005).

University of Melbourne . 2001. Records management manual. [Online] Available WWW: http://www.unimelb.edu.au/ (Accessed 21 March 2002).

Uwaifo, S.O. 2004. Management use of records in Delta State University, Abraka, Nigeria. Records Management Journal 14(2):85-89.

Wamukoya, J. 2000. Records and archives as a basis for good government: implications and challenges for records managers and archivists in Africa. Records Management Journal10 (1):23-33.

Wema, E. 2003. Problems of managing semi-active records in institutions of higher learning: the case of University of Dar Es Salaam. University of Dar es Salaam Library Journal 5 (1):46-56.

\section{Disclaimer}

Articles published in SAJIM are the opinions of the authors and do not necessarily reflect the opinion of the Editor, Board, Publisher, Webmaster or the Rand Afrikaans University. The user hereby waives any claim he/she/they may have or acquire against the publisher, its suppliers, licensees and sub licensees and indemnifies all said persons from any claims, lawsuits, proceedings, costs, special, incidental, consequential or indirect damages, including damages for loss of profits, loss of business or downtime arising out of or relating to the user's use of the Website. 
ISSN 1560-683X

Published by InterWord Communications for the Centre for Research in Web-based Applications, Rand Afrikaans University 